\title{
ANALISIS KEMAMPUAN BERPIKIR LOGIS PADA MATERI PELUANG DI KELAS IX SMP NEGERI 1 TAKENGON
}

\author{
Julia Noviani ${ }^{1}$, Hilda Hakim ${ }^{1}$, Jarwandi ${ }^{1}$ \\ ${ }^{1}$ Institut Agama Islam Negeri Takengon, Jalan Aman Dimot, Takengon 24519, Indonesia \\ Email: juliaanoviani@gmail.com \\ Email: hildahakim173@gmail.com \\ Email: wandijarwandi@gmail.com
}

\begin{abstract}
Abstrak
Kemampuan berpikir logis merupakan kemampuan yang sangat dibutuhkan dalam menghadapi tantangan era globalisasi ini. Kemampuan berpikir logis juga sangat erat kaitannya dengan kemampuan menyelesaikan masalah dalam matematika. Penelitian ini dilakukan berdasarkan fakta di yang terjadi di pada salah satu SMP Negeri di Takengon bahwa kemampuan berpikir logis siswa-siswa masih sangat kurang. Penelitian ini bertujuan untuk mendeskripsikan kemampuan berpikir logis siswa pada materi peluang pada kelas IX di SMP Negeri 1 Takengon. Penelitian ini menggunakan pendekatan kualitatif dengan jenis penelitian deskriptif. Subjek penelitian ini terdiri dari tiga orang siswa, dengan kriteria satu orang siswa berkemampuan tinggi, satu berkemampuan sedang, dan satu berkemampuan rendah. Pengumpulan data menggunakan tes dan wawancara semi terstruktur. Instrumen yang digunakan adalah tes materi peluang. Proses analisis data pada penelitian ini meliputi reduksi data, penyajian data, dan penarikan kesimpulan. Pada penelitian ini, peneliti menggunakan tiga tahapan berpikir logis yaitu keruntutan berpikir, kemampuan berargumen, dan penarikan kesimpulan. Berdasarkan analisis deskripsi kemampuan berpikir logis siswa dengan kriteria tinggi (siswa 1) menunjukkan kemampuan berpikir logis yang sangat baik. Kemudian siswa yang berkemampuan sedang (siswa 2) menunjukkan kemampuan berpikir logis yang cukup. Siswa berkemampuan sedang memiliki kekurangan pada tahapan keruntutan berpikir. Sedangkan siswa dengan kemampuan rendah (siswa 3) menunjukkan kemampuan berpikir logis yang kurang. Siswa berkemampuan rendah memiliki kekurangan pada tahapan keruntutan berpikir dan penarikan kesimpulan yang menunjukkan ketidaktelitian siswa tersebut.
\end{abstract}

Kata Kunci: Analisis, Berpikir Logis, Kemampuan Matematika

\begin{abstract}
Logical thinking ability is an ability that is needed to face the challenges of the globalization era. The ability to think logically is also very closely related to the ability to solve problems in mathematics. This research was carried out based on the facts in what happened at one of the state junior high schools in Takengon that the students' logical thinking ability was still lacking. This study aims to describe the ability of students to think logically on material opportunities in class IX in SMP Negeri 1 Takengon. This study used a qualitative approach with descriptive research. The subjects of this study consisted of three students, with the criteria of one student with high ability, one with moderate ability, and one with low ability. Data collection uses semistructured tests and interviews. The instrument used was probability test. The process of data analysis in the study include data reduction, data presentation, and conclusion. In this study, researchers used three stages of logical thinking namely thoughtfulness, argumentative ability, and conclusions. Based on the analysis of the description of students' logical thinking abilities with high criteria (student 1) shows excellent logical thinking skills. Then students of moderate ability (student 2) demonstrate sufficient logical thinking skills. Capable students are having deficiencies in the stage of thought disorder. While students with low ability (student 3 ) show less logical thinking skills. Low-ability students have deficiencies in the stage of thought disorder and drawing conclusions that indicate the inaccuracy of these students.
\end{abstract}

Keywords: Analysis, Logical Thinking, Mathematics Ability 


\section{PENDAHULUAN}

Matematika memiliki peranan penting dalam setiap ilmu pengetahuan. Matematika juga merupakan salah satu mata pelajaran yang menunjang keberhasilan siswa ke jenjang yang lebih tinggi. Tujuan dari pembelajaran matematika adalah siswa diharapkan mampu mengembangkan kemampuan bernalar yang logis, kritis, dan kreatif. Belajar matematika menuntut setiap siswa harus memiliki kemampuan memahami rumus, berhitung, menganalisis, mengelompokkan objek, membuat alat peraga, membuat model matematika dan lain-lain (Euis, 2014). Kemampuan berpikir logis, kritis dan kreatif saat ini menjadi kebutuhan manusia dalam menghadapi perkembangan ilmu pengetahuan dan persaingan global yang semakin ketat (Sumarmo, dkk, 2012). Oleh karena itu kemampuan berpikir logis sangat diperlukan dalam bertahan hidup di era globalisasi dan kemajuan teknologi sekarang ini. Kemampuan siswa secara mandiri dalam berpikir logis melibatkan tindakan logis yaitu analisis, sintesis, perbandingan serta generalisasi (O`ljayevna dan Shavkatovna, 2020). Matematika merupakan salah satu pelajaran yang dapat mengembangkan kemampuan berpikir logis tersebut. Pendapat lain mengenai berpikir logis disampaikan juga oleh Ni'matus (2011) yang menyatakan bahwa karakterisktik dari berpikir logis yaitu: (a) keruntutan berpikir; (b) kemampuan berargumen; (c) penarikan kesimpulan. Sehingga dapat disimpulkan berpikir logis adalah kemampuan berpikir dengan cara yang runtut dengan menggunakan fakta-fakta sehingga mampu berargumen dan dapat membuktikan kesimpulan secara benar.

Penelitian yang relevan mengenai kemampuan berpikir logis ini telah dilakukan oleh Budi Andriawan \& Mega Teguh Budiarto yang dilaksanakan pada siswa kelas VIII-1 SMP Negeri 2 Sidoarjo. Hasil penelitian dari penelitian tersebut, menunjukkan dalam kemampuan pemecahan masalah matematika, siswa melakukan kemampuan berpikir logis dengan runtut, dapat memberikan argumen serta menarik kesimpulan dengan benar. Akan tetapi juga terdapat siswa yang tidak dapat memberikan argumen serta tidak dapat menarik kesimpulan dari masalah matematika yang diberikan sehingga kemampuan berpikir logis tidak dapat ditunjukkan. Sedangkan penelitian yang dilakukan oleh Ni'matus (2011) menyatakan bahwa kemampuan berpikir logis sangat diperlukan pada proses pemecahan masalah, sehingga siswa yang mampu melakukan proses pemecahan masalah memiliki kemampuan berpikir logis yang baik. Berdasarkan uraian penelitian relevan tersebut mengungkapkan bahwa berpikir logis sangat penting dalam menyelesaikan masalah matematika.

Fakta di lapangan yang ditemukan oleh peneliti, yaitu dari hasil wawancara dengan guru matematika pada salah satu SMP negeri di Takengon ditemukan bahwa kemampuan berpikir logis siswa yang masih kurang. Hal tersebut terlihat pada hasil ulangan harian yang diberikan oleh guru sehingga nilai siswa masih dibawah KKM. I Made (2016) juga menyatakan bahwa kenyataan yang terjadi masih banyak siswa di sekolah-sekolah yang memiliki kemampuan berpikir rendah. Hal ini dibuktikan dari penelitian bahwa siswa merasa kebingungan untuk melakukan pengelompokan unsur langkah awal pengerjaan soal, kesalahan dalam melakukan operasi matematika, dan monoton terhadap contoh soal yang diberikan oleh gurunya.

Pada penelitian ini, peneliti akan menggunakan materi peluang untuk mendeskripsikan kemampuan berpikir logis siswa. Peneliti menganggap bahwa peluang merupakan salah satu pembelajaran yang sangat penting dalam matematika karena materi peluang merupakan konsep matematika yang dibutuhkan dalam kehidupan sehari-hari yaitu untuk memperkirakan suatu kejadian. Peneliti juga memandang materi peluang akan mengungkap kemampuan berpikir logis siswa sehingga mendapatkan data yang dibutuhkan dalam penelitian ini. Pertanyaan penelitian dalam penelitian ini adalah bagaimana kemampuan berpikir logis siswa pada materi peluang di kelas IX SMP Negeri 1 Takengon. Tujuan dari penelitian ini adalah mendeskripsikan kemampuan berpikir logis siswa pada materi peluang di kelas IX SMP Negeri 1 Takengon. 


\section{METODE PENELITIAN}

Pendekatan yang digunakan dalam penelitian ini adalah pendekatan kualitatif. Siswa yang dilibatkan dalam penelitian ini adalah siswa sekolah menengah pertama yang berjumlah 33 orang. Dari 33 siswa diberikan tes kemampuan awal matematika, kemudian dari tes kemampuan awal matematika tersebut terpilih tiga siswa yaitu satu siswa dengan kriteria tinggi, satu siswa dengan kriteria sedang, dan satu siswa dengan kriteria rendah untuk diwawancarai. Pemilihan siswa tersebut juga didasarkan pada wawancara dengan guru matematika yang mengajar di kelas mengenai kemampuan berpikir logis. Instrumen yang digunakan meliputi tes kemampuan kemampuan berpikir logis, dan wawancara semi terstruktur. Dalam penelitian ini, peneliti menggunakan wawancara semi terstruktur dengan mengajukan pertanyaan secara terbuka dan fleksibel terhadap subjek penelitian, namun tetap memperhatikan pedoman wawancara yang telah dirancang. Wawancara semi terstruktur dilakukan untuk mengkonfirmasi hasil tes siswa dan peneliti langsung yang mewawancarai siswanya berdasarkan hasil tes yang diperoleh. Tes yang diberikan berupa tes bentuk uraian dan penyusunannya disesuaikan dengan indikator kemampuan berpikir logis yang diukur. Proses analisis data pada penelitian ini meliputi reduksi data, penyajian data, dan penarikan kesimpulan. Tahapan dan indikator berpikir logis pada penelitian ini diadaptasi dari penelitian Ni'matus (2011).

Tabel 1. Tahapan dan Indikator Berpikir Logis

\begin{tabular}{|c|l|l|}
\hline No & Tahapan Berpikir Logis & \multicolumn{1}{|c|}{ Indikator } \\
\hline 1. & Keruntutan Berpikir & $\begin{array}{l}\text { Siswa menyebutkan seluruh informasi apa yang } \\
\text { diketahui dan apa yang ditanyakan dari soal dengan } \\
\text { tepat }\end{array}$ \\
\hline 2. & Kemampuan Berargumen & $\begin{array}{l}\text { Siswa dapat mengungkapkan alasan mengenai } \\
\text { seluruh langkah-langkah penyelesaian yang akan } \\
\text { digunakan dari awal hingga mendapat kesimpulan } \\
\text { dengan benar }\end{array}$ \\
\hline 3. & Penarikan kesimpulan & $\begin{array}{l}\text { Siswa memberikan kesimpulan dengan tepat pada } \\
\text { setiap langkah penyelesaian }\end{array}$ \\
& $\begin{array}{l}\text { Siswa mendapat suatu kesimpulan dengan tepat } \\
\text { pada akhir jawaban }\end{array}$ \\
\hline
\end{tabular}

\section{HASIL PENELITIAN DAN PEMBAHASAN}

\section{Tahapan Keruntuntan Berpikir}

Pada tahapan keruntutan berpikir, siswa diharapkan mampu menyebutkan seluruh informasi yang diketahui dan yang ditanyakan dari soal dengan tepat. Berdasarkan hasil petikan wawancara siswa yang berkemampuan tinggi, terlihat bahwa siswa mampu menyebutkan informasi apa yang diketahui dan apa yang ditanyakan dari soal dengan lengkap dan tepat sesuai yang diharapkan peneliti. Berikut hasil petikan wawancara bersama siswa dibawah ini:

$\mathrm{P}$ : Menurut kamu apa informasi yang diketahui (dari soal) yang diberikan?

$\mathrm{S}$ : Bahwa yang diketahui pelemparan 60 kali pelemparan sebuah dadu diperoleh mata dadu 1 munculnya 10 kali, mata dadu 2 munculnya 12 kali, mata dadu 3 munculnya 11 kali dan mata dadu 4 munculnya 8 kali.

$\mathrm{P}$ : Menurut kamu apa informasi yang ditanya (dari soal) yang diberikan? 
S : Tentukan peluang empirik muncul mata dadu kurang dari 4

$\mathrm{P}$ : Apakah kamu paham masalah yang ditanyakan pada soal yang deberikan

S : Iya, saya paham

Kemudian siswa yang memiliki kemampuan sedang, berdasarkan hasil cuplikan wawancara siswa terlihat bahwa siswa dapat menyebutkan informasi yang diketahui dan yang ditanyakan dari soal namun tidak lengkap.

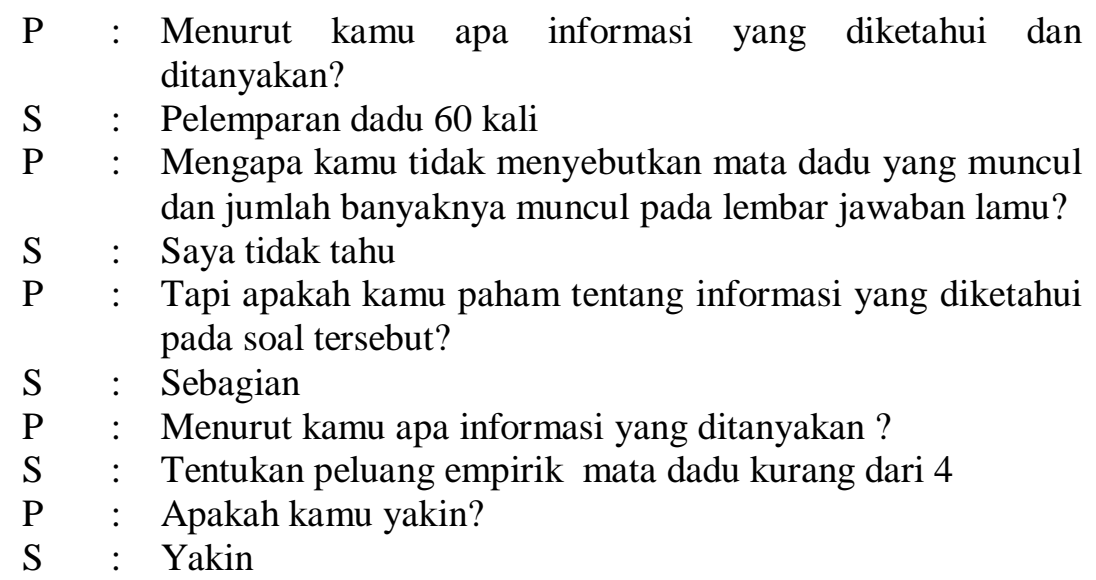

Dari hasil petikan wawancara di atas yang menunjukkan bahwa siswa hanya mengetahui sebagian dari informasi soal tersebut. Sedangkan siswa berkemampuan rendah dalam tahapan keruntutan berpikir tidak dapat menyebutkan apa informasi yang diketahui dan apa informasi yang ditanyakan. Namun uniknya siswa tersebut langsung membuat langkah-langkah penyelesaiaannya saja.

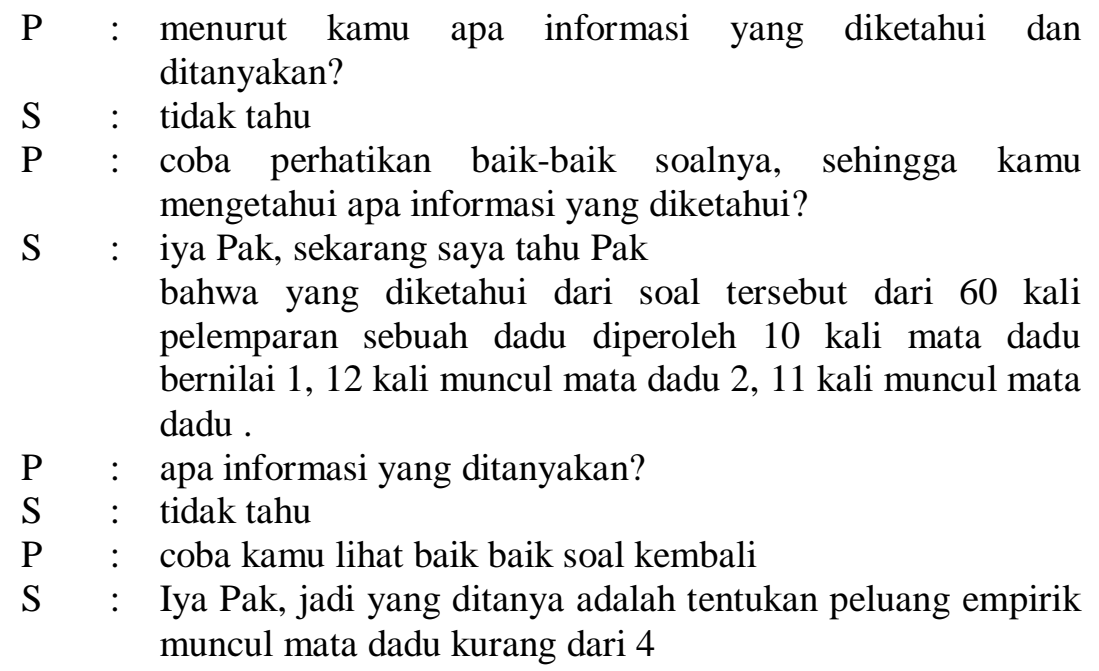

Analisis siswa yang berkemampuan rendah pada kriteria keruntutan berpikir bahwa siswa tidak dapat menuliskan informasi yang diketahui dan ditanyakan terlihat pada hasil kerja siswa diatas. Namun pada hasil petikan wawancara siswa, setelah dikonfirmasi oleh peneliti siswa tersebut akhirnya dapat menyebutkan informasi yang diketahui dan ditanyakan. 


\section{Tahapan Kemampuan Berargumen}

Tahapan kemampuan berargumen yang diharapkan peneliti yaitu siswa dapat mengungkapkan alasan mengenai seluruh langkah-langkah penyelesaian yang akan digunakan dari awal hingga mendapat kesimpulan dengan benar. Pada siswa yang memiliki kemampuan tinggi memiliki kemampuan berargumen yang diharapkan oleh peneliti. Hal tersebut terlihat dari hasil petikan wawancara siswa:

P : Bagaimana kamu menentukan peluang empirik muncul mata dadu kurang dari 4 ?

$\mathrm{S}$ : Untuk menentukan peluang peluang empirik muncul mata dadu kurang dari 4 berarti muncul mata dadu $(3,2,1)$ sedangkan nilai yang muncul mata dadu 3 sebanyak 11 kali, mata dadu dua muncul 12 kali dan mata dadu 1 muncul 1 kali. Sedangkan jumlah pelemparan sebanyak $n(S)=60$ kali

$\mathrm{P}\left(\right.$ kurang dari 4) $=\frac{n(\text { kurang dari } 4)}{n(S)}=$
$\frac{\text { mata dadu muncul 3,2,1) }}{n(S)}=\frac{(11+12+10)}{60}=33 / 60$

$\mathrm{P} \quad$ : Apakah kamu yakin pada penyelesaian ini

S : Iya, saya yakin

P : Coba kamu jelaskan setiap langkah-langkah yang kamu dapatkan

S : Langkah pertama saya memahami kembali apa yang ditanyakan dari soal jadi saya membuat penyelesaian bahwa pada soal tersebuat ditanyakan peluang empirik muncul mata dadu kurang dari 4. Untuk menentukan peluang peluang empirik muncul mata dadu kurang dari 4 berarti muncul mata dadu $(3,2,1)$ sedangkan nilai yang muncul mata dadu 3 sebanyak 11 kali, mata dadu dua muncul 12 kali dan mata dadu 1 muncul 1 kali. Sedangkan jumlah pelemparan sebanyak $\mathrm{n}(\mathrm{S})=$ 60 kali

$\mathrm{P}\left(\right.$ kurang dari 4) $=\frac{n(\text { kurang dari } 4)}{n(S)}=$
$\frac{\text { mata dadu muncul } 3,2,1)}{n(S)}=\frac{(11+12+10)}{60}=33 / 60$

Kemudian siswa yang memiliki kemampuan sedang juga mampu mengungkapkan alasan logis mengenai seluruh langkah-langkah penyelesaian, terlihat pada hasil petikan wawancara berikut.

P : coba kamu jelaskan setiap langkah-langkah yang kamu buat untuk menentukan peluang empirik muncul mata dadu kurang dari 4 ?

$\mathrm{S} \quad$ : untuk menentukan peluang empirik kurang dari 4 p kurang dari 4. $\mathrm{p}($ kurang dari 4$)=\mathrm{n}(\mathrm{A}) / \mathrm{n}(\mathrm{S})$ peluang muncul mata dadu kurang dari 4 berarti pernah muncul mata dadu $(3,2,1)$ dijumlahkan nilai mata dadu berapa kali muncul $(11+12$ $+10)=33$ setelah itu baru kita selesaikan dengan jumlah seluruh 
pelemparan mata dadu $\mathrm{P}=\mathrm{n}(\mathrm{A}) / \mathrm{n}(\mathrm{S})=33 / 60$

Sedangkan siswa yang berkemampuan rendah, terlihat bahwa siswa menyelesaikan soal yang diberikan namun tidak terlalu lengkap saat mengungkapkan argumen pada saat wawancara.

P : coba kamu jelaskan setiap langkah-langkah yang kamu buat untuk menentukan peluang empirik muncul mata dadu kurang dari 4 ?

S : untuk menentukan peluang empirik kurang dari 4 muncul mata dadu kurang dari 4 $\mathrm{P}(\mathrm{A})=(3,2,1)$ kemudian dijumlah jumlah mata dadu yang muncul

dijumlahkan nilai mata dadu berapa kali muncul $(11+12$ $+10)=33$ kali

\section{Tahapan Penarikan Kesimpulan}

Tahapan penarikan kesimpulan memiliki indikator yaitu siswa memberikan kesimpulan dengan tepat pada setiap langkah penyelesaian dan siswa mendapatkan suatu kesimpulan dengan tepat pada akhir jawaban. Untuk siswa berkemampuan tinggi, siswa mampu membuat kesimpulan dari soal yang diberikan.

P : Apakah pada setiap langkah-langkah penyelesaian yang kamu buat sudah yakin itu benar?

$\mathrm{S}$ : Iya, in sya Allah saya yakin

P : Jelaskan kesimpulan yang kamu dapatkan dari setiap langkah langkah yang adek buat?

S : Kesimpulan bahwa peluang empirik muncul mata dadu kurang dari 4 berarti muncul mata dadu $(3,2,1)$ sedankan nilai yang muncul mata dadu 3 sebanyak 11 kali, mata dadu dua muncul 12 kali dan mata dadu 1 muncul 1 kali. Sedangkan jumlah pelemparan sebanyak $n(S)=60$ kali

$\mathrm{P}($ kurang dari 4$)=\frac{n(\text { kurang dari } 4)}{n(S)}=\frac{\text { mata dadu muncul } 3,2,1)}{n(S)}=$ $\frac{(11+12+10)}{60}=33 / 60$

$\mathrm{P}$ : Apakah kamu yakin dengan jawaban tersebut

S : Insya Allah, saya yakin

Kemudian siswa yang memiliki kemampuan sedang pada proses penarikan kesimpulan, peneliti kemudian mencoba mewawancarai siswa tersebut dan dari hasil petikan wawancara ia terlihat mampu membuat kesimpulan. 
P: coba kamu jelaskan setiap langkah-langkah yang kamu buat untuk menentukan peluang empirik muncul mata dadu kurang dari 4 sehingga mendapatkan kesimpulan?

S: $\quad$ untuk menentukan peluang empirik kurang dari 4

p kurang dari 4.

peluang empirik $\mathrm{P}(\mathrm{A})=\mathrm{n}(\mathrm{A}) / \mathrm{n}(\mathrm{S})$ peluang muncul mata

$\mathrm{n}(\mathrm{A})=$ frekuensi kejadian $\mathrm{A}$

$\mathrm{f}(\mathrm{s})$ frekuensi percobaan

muncul mata dadu kurang dari 4

$\mathrm{P}(\mathrm{A})=(3,2,1)$ kemudian dijumlah jumlah mata dadu yang muncul

dijumlahkan nilai mata dadu berapa kali muncul $(11+12+10)=33$ kali

jadi kesimpulannya adalah 33/60

Sedangkan siswa yang berkemampuan rendah, berdasarkan hasil kerja siswa, terlihat bahwa siswa memberikan kesimpulan namun kesimpulan tersebut keliru, kurang lengkap dan tidak sesuai dengan hasil yang sebelumnya. Siswa tersebut tidak teliti dan hati-hati dalam proses penarikan kesimpulan.

P: Coba kamu jelaskan setiap langkah-langkah yang kamu buat untuk menentukan peluang empirik muncul mata dadu kurang dari 4 sehingga mendapatkan kesimpulan?

S: $\quad$ Untuk menentukan peluang empirik kurang dari 4 p kurang dari 4.

muncul mata dadu kurang dari 4

$\mathrm{P}(\mathrm{A})=(3,2,1)$ kemudian dijumlah jumlah mata dadu yang muncul

dijumlahkan nilai mata dadu berapa kali muncul $(11+12+10)=33$ kali

P: $\quad$ Tapi kamu menjawabnya 30?

S: $\quad$ Oh, salah tulis saya Pak, jawabannya 33

P: Yakin 33?

S: Iya Pak.

Dari hasil petikan wawancara yang dilakukan bersama siswa yang memiliki kemampuan tinggi, sedang dan rendah, peneliti merangkum kemampuan berpikir logis siswa dalam tabel berikut.

Tabel 2. Data Penelitian Kemampuan Berpikir Logis

\begin{tabular}{|c|l|l|}
\hline $\begin{array}{c}\text { Subjek } \\
\text { Penelitian }\end{array}$ & Tahapan Berpikir Logis & \multicolumn{1}{c|}{ Data Penelitian } \\
\hline \multirow{5}{*}{ Siswa 1 } & Keruntutan Berpikir & $\begin{array}{l}\text { Siswa mampu menyebutkan informasi apa yang } \\
\text { diketahui dan apa yang ditanyakan dari soal } \\
\text { dengan lengkap dan tepat sesuai yang diharapkan } \\
\text { peneliti }\end{array}$ \\
\cline { 2 - 4 } & Kemampuan berargumen & $\begin{array}{l}\text { Siswa dapat mengungkapkan alasan mengenai } \\
\text { seluruh langkah-langkah penyelesaian yang akan } \\
\text { digunakan dari awal hingga mendapat kesimpulan } \\
\text { dengan benar }\end{array}$ \\
\cline { 2 - 4 } & Penarikan kesimpulan & $\begin{array}{l}\text { Siswa memberikan kesimpulan dengan tepat pada } \\
\text { setiap langkah penyelesaian dan siswa } \\
\text { mendapatkan suatu kesimpulan dengan tepat pada } \\
\text { akhir jawaban }\end{array}$ \\
\hline
\end{tabular}




\begin{tabular}{|c|l|l|}
\hline $\begin{array}{c}\text { Subjek } \\
\text { Penelitian }\end{array}$ & Tahapan Berpikir Logis & \multicolumn{1}{|c|}{ Data Penelitian } \\
\hline \multirow{5}{*}{ Siswa 2 } & Keruntutan Berpikir & $\begin{array}{l}\text { Siswa dapat menyebutkan informasi yang } \\
\text { diketahui dan yang ditanyakan dari soal namun } \\
\text { tidak lengkap }\end{array}$ \\
\cline { 2 - 4 } & Kemampuan berargumen & $\begin{array}{l}\text { Siswa mampu mengungkapkan alasan logis } \\
\text { mengenai seluruh langkah-langkah penyelesaian }\end{array}$ \\
\cline { 2 - 4 } & Penarikan kesimpulan & $\begin{array}{l}\text { Siswa memberikan kesimpulan dengan tepat pada } \\
\text { setiap langkah penyelesaian dan siswa } \\
\text { mendapatkan suatu kesimpulan dengan tepat pada } \\
\text { akhir jawaban dan }\end{array}$ \\
\hline \multirow{5}{*}{ Siswa 3 } & Keruntutan Berpikir & $\begin{array}{l}\text { Siswa tidak dapat menyebutkan apa informasi } \\
\text { yang diketahui dan apa informasi yang ditanyakan }\end{array}$ \\
\cline { 2 - 4 } & Kemampuan berargumen & $\begin{array}{l}\text { Siswa menyelesaikan soal yang diberikan namun } \\
\text { tidak terlalu lengkap saat mengungkapkan } \\
\text { argumen }\end{array}$ \\
\cline { 2 - 4 } & Penarikan kesimpulan & $\begin{array}{l}\text { Siswa memberikan kesimpulan namun } \\
\text { kesimpulan tersebut keliru, kurang lengkap dan } \\
\text { tidak sesuai dengan hasil yang sebelumnya }\end{array}$ \\
\hline
\end{tabular}

\section{Kemampuan Berpikir Logis Subjek Berkemampuan Tinggi}

Subjek berkemampuan tinggi dapat memenuhi ketiga tahapan berpikir logis, yaitu keruntutan berpikir, kemampuan berargumen dan penarikan kesimpulan. Pada tahapan keruntutan berpikir, subjek berkemampuan tinggi mampu menyebutkan informasi dengan jelas apa yang diketahui dan apa yang ditanyakan dari soal dengan lengkap dan tepat sesuai yang diharapkan peneliti. Tahapan kemampuan berargumen, subjek berkemampuan tinggi dapat mengungkapkan alasan secara logis dan sistematis mengenai seluruh langkah-langkah penyelesaian yang akan digunakan dari awal hingga mendapat kesimpulan dengan benar. Tahapan penarikan kesimpulan, siswa memberikan kesimpulan dengan tepat pada setiap langkah penyelesaian sehingga siswa mendapatkan suatu kesimpulan dengan tepat pada akhir jawaban. Dari keseluruhan tahapan berpikir logis beserta indikatornya, subjek berkemampuan tinggi telah menunjukkan kemampuan berpikir logis yang baik. Hal ini juga sejalan dengan penelitian yang dilakukan oleh Alfin, Warli dan Surawan (2017) yang menyatakan bahwa subjek berkemampuan tinggi mampu memenuhi kriteria berpikir logis yang baik, yaitu analogi, penalaran probabilitas, penalaran kombinatorial, dan controlling variabel.

\section{Kemampuan Berpikir Logis Subjek Berkemampuan Sedang}

Subjek berkemampuan sedang pada tahap keruntutan berpikir dapat menyebutkan informasi yang diketahui dan yang ditanyakan dari soal namun tidak lengkap. Siswa hanya menyebutkan sebagian informasi saja dari soal yang diberikan. Pada tahap kemampuan beragurmen, siswa mampu mengungkapkan alasan logis mengenai seluruh langkah-langkah penyelesaian namun tidak selengkap siswa berkemampuan tinggi. Pada tahap penarikan kesimpulan, siswa mampu memberikan kesimpulan yang benar pada akhir jawaban. Dari keseluruhan tahapan berpikir logis beserta indikatornya, subjek berkemampuan sedang telah menunjukkan kemampuan berpikir logis yang cukup. Hal ini juga sejalan dengan penelitian yang dilakukan oleh Alfin, Warli dan Surawan (2017) yang menyatakan bahwa subjek berkemampuan sedang, subjek hanya mampu memenuhi indikator penalaran kombinatorial dan controlling variabel. Subjek berkemampuan sedang tidak dapat 
memenuhi indikator analogi dan penalaran probabilitas sehingga subjek berkemampuan sedang digolongkan memiliki kemampuan berpikir logis cukup.

\section{Kemampuan Berpikir Logis Subjek Berkemampuan Rendah}

Subjek berkemampuan rendah pada tahap keruntutan berpikir tidak dapat menyebutkan apa informasi yang diketahui dan apa informasi yang ditanyakan, sehingga subjek berkemampuan rendah tidak memenuhi tahapan keruntutan berpikir. Pada tahap kemampuan berargumen, subjek berkemampuan rendah ketika menyampaikan alasan dari langkah-langkah penyelesaian tidak lengkap. Pada tahap penarikan kesimpulan, siswa memberikan kesimpulan namun kesimpulan tersebut keliru, kurang lengkap dan tidak sesuai dengan hasil yang sebelumnya. Dari keseluruhan tahapan berpikir logis, subjek berkemampuan rendah memiliki kekurangan pada tahap keruntutan berpikir dan penarikan kesimpulan, sehingga hal ini menyebabkan kemampuan berpikir logis subjek tersebut kurang. Penelitian Alfin, Warli dan Surawan (2017) juga menyatakan subjek berkemampuan rendah hanya memenuhi satu indikator saja, yaitu penalaran kombinatorial, sedangkan indikator lainnya subjek tersebut tidak mampu memenuhinya sehingga kemampuan berpikir logis subjek berkemampuan rendah tergolong kurang.

\section{KESIMPULAN}

Hasil penelitian ini terlihat bahwa siswa dengan kemampuan tinggi menunjukkan kemampuan berpikir logis yang sangat baik. Kemudian siswa yang berkemampuan sedang (siswa 2) menunjukkan kemampuan berpikir logis yang cukup. Siswa berkemampuan sedang memiliki kekurangan pada tahapan keruntutan berpikir. Sedangkan siswa dengan kemampuan rendah menunjukkan kemampuan berpikir logis yang kurang. Siswa 3 memiliki kekurangan pada tahapan keruntutan berpikir dan penarikan kesimpulan yang menunjukkan ketidaktelitian siswa tersebut. Penelitian ini juga memperlihatkan bahwa butuh waktu yang cukup untuk membiasakan siswa melatih kemampuan berpikir logis dalam pembelajaran matematika.

\section{REFERENCES}

Alfin. Warli. Surawan. (2017). Profil Berpikir Logis Siswa ditinjau dari Kemampuan Matematika. Prosiding Seminar Nasional Hasil Penelitian dan Pengabdian kepada Masyarakat II Universitas PGRI Ronggolawe Tuban. 2(1), 257-262. Retrieved from http://prosiding.unirow.ac.id/index.php/SNasPPM/article/download/118/118/.

Albrecht, K. (1992). Daya Pikir. Semarang: Dahar Prize.

Andriawan, B. \& Budiarto, M.T. (2014). Identifikasi Kemampuan Berpikir Logis Dalam Pemecahan Masalah Matematika Pada Siswa Kelas VIII-1 SMP Negeri 2 Sidoarjo. Jurnal Mathedunesa, 3 (2), 42-48. Retrieved from https://jurnalmahasiswa.unesa.ac.id/index.php/mathedunesa/article/view/8657.

Hadi, Sutrisno. (2004). Metodologi Research Jilid 3. Yogyakarta: Andi

Miles, M.B \& Huberman, A.M, dan Saldana, J. (2014). Qualitative Data Analysis, A Methods Sourcebook, Edition 3. USA: Sage Publication Terjemahan Tjetjep Rohindi, UI-Press

Ni'matus. 2011. Kemampuan Berpikir Logis Siswa dalam Pemecahan Masalah Matematika Siswa Kelas VII-C SMP Negeri 12 Surabaya. Skripsi Tidak Dipublikasikan. Surabaya: Unesa. 
O`ljayevna, O., \& Shavkatovna, S. (2020). The Development of Logical Thinking of Primary School Students in Mathematics. European Journal of Research and Reflection in Educational Sciences, 8(2), 235-239. Retrieved from http://www.idpublications.org/wpcontent/uploads/2020/03/Full-Paper-THE-DEVELOPMENT-OF-LOGICAL-THINKING-OFPRIMARY-SCHOOL-STUDENTS-IN-MATHEMATICS.pdf

Setiawati, Euis, (2014). Mengembangkan Kemampuan Berpikir Logis, Kreatif, dan Habits of Mind Matematika Melalui Pembelajaran Berbasis Masalah (Eksperimen terhadap Siswa Madrasah Aliyah), Tesis Universitas Pendidikan Indonesia.

Siswono, Tatag Yuli Eko. 2008. Model Pembelajaran Berbasis Pengajuan dan Pemecahan Masalah Untuk Meningkatkan Kemampuan Berpikir Kreatif. Surabaya: Unesa University Press.

Sugiyono. 2008. Metode Penelitian Kuantitatif, Kualitatif dan R\&D. Bandung: Alfabeta.

Sumarmo, Utari, dkk. (2012). Kemampuan dan Disposisi Berpikir Logis, Kritis dan Kreatif Matematika (Eksperimen Terhadap Siswa SMA Menggunakan Pembelajaran Berbasis Masalah dan Stratge Think Talk Write). Jurnal Pengajaran MIPA, 17(1), 17-33. Retrieved from http://journal.fpmipa.upi.edu/index.php/jpmipa/article/view/228.

Surat, I Made. (2016). Pembentukan Karakter Berpikir Logis Siswa, Melalui Pembelajaran Matematika Saintifik. Jurnal Emasains, 58(1), 57-65. Retrived from https://ojs.ikippgribali.ac.id/index.php/emasains/article/download/20/17/ 